\title{
Interrogating differences: A comparative analysis of Africa's informal settlements
}

\author{
Zora Kovacic $^{\mathrm{a}, *}$, Josephine Kaviti Musango ${ }^{a}$, Lorraine Amollo Ambole ${ }^{\mathrm{b}}$, Kareem Buyana ${ }^{\mathrm{c}}$, Suzanne Smit ${ }^{\mathrm{a}}$, \\ Christer Anditi ${ }^{b}$, Baraka Mwau ${ }^{\mathrm{d}}$, Madara Ogot ${ }^{\mathrm{e}}$, Shuaib Lwasa ${ }^{\mathrm{c}}$, Alan C. Brent ${ }^{\mathrm{f}, \mathrm{g}}$, Gloria Nsangi ${ }^{\mathrm{c}}$, \\ Hakimu Sseviiri $^{\mathrm{C}}$
}

${ }^{a}$ School of Public Leadership; urban Modelling and Metabolism Assessment (uMAMA), Stellenbosch University, South Africa

${ }^{\mathrm{b}}$ School of the Arts and Design, University of Nairobi, Kenya

${ }^{\mathrm{c}}$ Urban Action Lab, Makerere University, Uganda

${ }^{\mathrm{d}}$ Urban Planning and Research Consultant, Nairobi, Kenya

${ }^{e}$ Department of Mechanical \& Manufacturing Engineering, University of Nairobi, Kenya

${ }_{\mathrm{f}}^{\mathrm{f}}$ Department of Industrial Engineering, Centre for Renewable and Sustainable Energy Studies (CRSES), Stellenbosch University, South Africa

${ }^{\mathrm{g}}$ Sustainable Energy Systems, Engineering and Computer Science, Victoria University of Wellington, New Zealand

\section{A R T I C L E I N F O}

\section{Article history:}

Accepted 7 June 2019

Available online 29 June 2019

\section{Keywords}

Slums

Gender

Health

Energy

Social metabolism

Co-design

\begin{abstract}
A B S T R A C T
Urban development in Africa is a very diverse and ambivalent phenomenon with aspects that do not fall neatly into global standards. Informal settlements therefore challenge governance by standards. We argue that quantifying and interrogating differences offers a better basis for governance. By drawing on a comparative analysis of three different informal settlements in Sub-Saharan Africa, this paper explores what differences reveal about the governance of informal settlements. The paper uses an urban societal metabolism approach, focussed on gender, energy and health, based on questionnaires and focus group discussions in Enkanini (Stellenbosch, South Africa), Mathare (Nairobi, Kenya), and KasubiKawaala (Kampala, Uganda). The contribution of the paper is both empirical and theoretical. Empirically, we provide new evidence about the metabolism of urban informality at multiple levels of analysis: the individual, the household and the settlement. Findings show the gender asymmetries in urban poverty and the intricate links between energy choices, health and economic status. Theoretically, we argue that different levels of analysis produce different understandings of urban informality, and that analyzing informal settlements only by population aggregates means missing information. We conclude by arguing that understanding differences leads to the formulation of modest and localised goals, which are better able to take into account the complexity of urban informality.
\end{abstract}

(c) 2019 Elsevier Ltd. All rights reserved.

\section{Introduction}

The study of urban informality is characterised by the tension between the need to count and monitor informal settlements and living conditions and the need to avoid one-size-fits-all definitions and policies. Accounting is necessary to raise awareness about the extent of urban informality and to assess the effect of policies. The United Nations (UN) reports on global slum population have been instrumental to communicate the magnitude of the phenomenon and to set development priorities, such as

\footnotetext{
* Corresponding author.

E-mail addresses: zora@umama-africa.com (Z. Kovacic), jmusango@sun.ac.za (J.K. Musango), madaraogot@uonbi.ac.ke (M. Ogot), alan.brent@vuw.ac.nz
} (A.C. Brent). through the inclusion of a goal on cities in Sustainable Development Goals of 2015 (Talukdar, 2018). Statistics, however, tend to rely on averages and overlook differences. Recurrent debates involve the definition of poverty lines (Lucci, Bhatkal, \& Khan, 2018), the multi-dimensional character of poverty (Alkire \& Santos, 2014), and the inadequacy of accounting methods originally developed for rural poverty to account for urban poverty (Gibson, 2015). Lucci et al. (2018) argue that urban poverty is underestimated due to a number of biases in accounting, and Pasha (2017) discusses the difficulty of establishing weighting factors for different contexts.

Following these debates, efforts have been devoted to a careful use of terms and definitions and to comparative studies that emphasise the differences between informal settlements. The multiplicity of terms used to refer to informal settlements, such as 
slum, shantytown, squatter settlements, self-help housing, and the existence of one or more expressions in different languages that refer to informal settlements, such as favela, bidonville, gecekondu, indicate both the broadness and diversity of this urban phenomenon (Gilbert, 2007; Nuissl \& Heinrichs, 2013). Eckstein (1990) seminal paper distinguishes between inner city slums of hope and squatter settlements of despair, bringing attention to differences within the same city. Nuance in definitions, however, is not translated in nuance in the use of statistics and indicators.

The UN-HABITAT defines an informal settlement as a slum if it displays one or more of the following characteristics: "(i) inadequate access to safe water; (ii) inadequate access to sanitation and other infrastructure; (iii) poor structural quality housing; (iv) overcrowding; and (v) insecure residential status" (UN-HABITAT, 2003: 12). This operational definition is proposed by the UN as a way to count informal settlements and monitor their emergence and development, but the report makes clear that informal settlements are a complex and varied phenomenon, which is hard to capture in metrics. According to Scott (1998), statistics make it possible to govern "at a distance," by transforming specificities and differences in statistical averages, standardised weights and measures. Census data are an example of such standardisation through quantification, which gives rise to "a population" from many different individuals, and produces a subject that can be governed by the state. Standard measurements and governance are closely linked.

Informal settlements are a failure of standardisation, and therefore, defy governance by standards. Urban informality arises from the limits of formal systems and standard housing to provide for the urban poor. According to UN-HABITAT, "slums must be seen as the result of a failure of housing policies, laws and delivery systems, as well as of national and urban policies" (2003: 5). The absence of standards is interpreted as a failure of governance. We argue that the governance failure associated with informal settlements cannot be remedied with the same tools used to standardise housing policies and urban planning. It is necessary to quantify and interrogate the diversity of informal settlements. While a lot of research has discussed social, political and economic differences across informal settlements (Roy, 2005; Roy \& AlSayyad, 2004), quantitative analysis has lagged behind, and has focused mainly on classifying and categorising physical differences in building structure, infrastructures and morphology (Acloly, 2000).

To remedy this gap, we analyse three informal settlements in Sub-Saharan Africa, which have very different characteristics and pose different challenges for governance. The purpose of this paper is to assess the relationship between governance and quantification in the context of informality and irreducible differences. The paper asks, what do differences reveal about the use of quantitative data in the governance of urban informality? To this purpose, we administered 300 questionnaires in three informal settlements, namely: Enkanini in Stellenbosch (South Africa), Mathare in Nairobi (Kenya), and Kasubi-Kawaala in Kampala (Uganda), described in Section 2. Based on the insight that different analytical units yield different understandings of urban informality (Gulyani \& Talukdar, 2010), we used different levels of analysis hailing from the urban societal metabolism approach to analyse differences. We validated the interpretation of results through participatory research methods through an iterative approach described in Section 3. The societal metabolism approach analyses expected relations between the characteristics of a society, for example, between changes in population and in corresponding energy demand. This method identifies patterns but is not deterministic about quantitative relations, that is, it does not establish monodirectional causality. This approach can be associated with the type of comparative analysis described by Pickvance (2001) as aimed at showing differences and assuming multiple causalities.

It should be noted that statistics for the most part illustrate the deprived side of informal settlements, overlooking opportunities to innovate and experiment using local capacity. This misses the ambivalent nature of African informal settlements. Informal settlements do not represent only failures and deficiencies in urban planning and governance, but are also innovative and inventive urban environments, with micro-scale solutions that can have a positive effect in dealing with interconnected sustainability challenges. While recognising the importance of taking into account local knowledge, we do not mean to romanticise urban poverty. The focus on the innovative and entrepreneurial capacity of informal dwellers has been used by De Soto to inform World Bank policy in support of a roll-back of government and a neoliberal approach to the governance of informal settlements (Bromely, 2004). Huchzermeyer (2006) warns that governance should not divert attention from the need to eradicate poverty, vulnerability and promote inclusion. We therefore made an effort to include local communities in the production of knowledge and metrics about informal settlements, while maintaining a reflexive approach towards our results and research methods. For this reason, in the presentation of our method and research design we reflect about how our own accounting practices matter for the understanding of informal settlements and for community engagement.

The contribution of the paper is both empirical and theoretical. Empirically, we provide new evidence about the metabolism of urban informality at multiple levels of analysis: the individual, the household and the settlement. We use these multiple representations as a means of comparing the three settlements and of explaining differences from multiple points of view (Section 4). In the discussion, we advance a theoretical argument for the levels of analysis that are needed to articulate context-specific policies for the governance of urban informality. Quantitative data are not used as a means to measure the magnitude of urban informality but as a way to identify discontinuities and differences as entry points for governance. We conclude the paper by arguing that understanding differences leads to the formulation of modest goals, which avoid policy paralysis in the context of complexity.

\section{Case studies}

This section describes the three case studies used in this paper, and the different policy challenges they present. We briefly mention the history of the settlements to show that governance challenges change in time, as informal settlements develop in different directions. The three case studies were selected because they represent different types of informal settlements and because they show that urban informality can evolve in different ways.

Enkanini is the most recent informal settlement of our study. Enkanini was established in 2006, as dwellers occupied municipal land that belongs to the city of Stellenbosch, South Africa. The settlement does not receive electricity provision, waste collection services, health services. Due to its recent formation, the population of the settlement is composed mostly of young adults. The settlement had about 8000 people as of 2015 (Kovacic, Smit, Musango, Brent, \& Giampietro, 2016; Smit, Musango, Kovacic, \& Brent, 2018). Enkanini is inhabited mainly by people that work as domestic workers and security guards in Stellenbosch (Smit et al., 2018). This case study raises questions about the relational character of informality, which is linked to demand for low paid labour and driven by high levels of inequality. Demand for cheap labour and lack of access to formal housing due to low wages are two drivers of the emergence 
of informal settlements. Policy needs in this case are related to the question of limiting the emergence and expansion of informal settlements, and of providing basic services to unrecognised and unmonitored settlements.

The case studies of Mathare and Kasubi-Kawaala suggest two possible development paths, of many, that long-established informal settlements may follow. Mathare was established in the 1960s in Nairobi (Andvig \& Barasa, 2014) following Kenya's independence in 1963. It is closely connected to the legacy of colonialism, during which time the city was racially zoned and the poor were segregated to the city outskirts. Mathare is a large settlement composed of 13 villages and home to over 190,000 people. Mathare suffers from consolidated forms of stigmatisation, which can be linked to the historical association of the informal settlement with prostitution (Nelson, 1978), the high incidence of illegal activities, such as youth cartels, the presence of drug traffickers, as well as the deplorable health conditions of the settlement, which suffers from recurrent cholera outbreaks (Nyamogoba, Obala, \& Kakai, 2002). Over half of the economic activity of the informal settlement hails from small informal businesses developed within the settlement, as discussed in Section 4, which are often linked to the formal economy but are excluded from social security and other public welfare systems. These trends reveal a social challenge of stigmatisation and marginalisation, a political challenge of law enforcement with regard to land tenure and utility provision, and an economic challenge of integrating the informal city in the formal urban area.

Finally, Kasubi-Kawaala may be seen as an informal settlement that is transitioning to a formal neighbourhood, economically and socially integrated in the city of Kampala, Uganda, but which retains a high incidence of poverty. Kasubi-Kawaala, founded in 1856, is the oldest of the three settlements, an (Ministry of Lands Housing and Urban Development, 2014), and is home to about 90,000 people (Uganda Bureau of Statistics, 2014). KasubiKawaala is considered a slum according to the UN definition, but it is formally serviced by water, electricity, schools and hospitals. It provides an example of where the distinction between the slums and the city is blurred, as between $49 \%$ and $64 \%$ of the urban population of Kampala live in informal settlements (Ministry of Lands Housing and Urban Development, 2014). Economic integration can be observed in the presence of the Kasubi market, managed by Kampala Capital City Authority, which employs a large amount of residents (Section 4). Social integration can be seen in the presence of a varied social fabric, which consists of both poor and wealthier households, as well as university students, and signals a low level of stigmatisation. In this case, the main challenge that emerges is one of poverty reduction. This case study reveals that informality and poverty are not necessarily linked and that policies that tackle informality may not be sufficient to reduce poverty.

The differences between the three settlements can be further specified using the typology developed by Smit et al. (2017). Enkanini belongs to type C: Informal (developed by informal settlers), Illegal (without security of tenure, legal claim to land, not in compliance with health and safety laws), Unplanned (settlement layout and infrastructure driven by settlers), and Illegitimate (not recognised by the municipality). Mathare is type E: hybrid, multistructured settlement, which is Informal (developed by informal settlers), but ranges from Legal/Illegal (some settlers and villages have obtained land titles), Planned/Unplanned (in some villages infrastructure is formally provided and settlement layout is planned) and Legitimate/Illegitimate (some villages are formally recognised). Kasubi-Kawaala is type A: Formal (developed by official, including government, entities), Legal (with regard to security of tenure, although due to overcrowding and lack of maintenance, some houses no longer adhere to legal requirements in terms of health, safety and building regulations), Planned (infrastructure and service provision is designed and provided by formal entity) and Legitimate (the settlement is formally recognised).

\section{Methods and materials}

This paper utilises an urban societal metabolism approach. Societal metabolism is a metaphor used to create an analogy between the study of organisms and that of society. Societal metabolism asks how societies reproduce themselves and analyses the throughput of materials, energy and water used to sustain economic activities. We use this approach because it provides a nondeterministic characterisation of trends based on expected metabolic patterns. Quantitative information is not used to estimate averages or statistical relations, but as a means to establish benchmarks of expected characteristics without erasing differences. For instance, one can expect the temperature of human beings to be around $37^{\circ} \mathrm{C}$, yet this quantitative definition cannot be used to predict the height of a person. Similarly, in societal metabolism one can expect to find patterns of time use. In a study of the countries of the European Union, Giampietro, Mayumi, and Sorman (2013) found that only about $10 \%$ of the time available to society is used in paid work activities. This result was consistent across all countries analysed, indicating a metabolic pattern. This pattern, however, is not causally correlated to other variables, such as income or energy throughput, and cannot be used to make predictions about other variables. Societal metabolism can thus be used to study patterns while maintaining differences.

There are three main streams of urban metabolism (Kennedy, Pincetl, \& Bunje, 2011) primarily used to study: (i) the demand of water and energy of cities, and the associated waste streams of wastewater and air pollution (following the pioneering work of Wolman (1965); (ii) the historical evolution of cities, and changes in its interaction with and use of the surrounding ecosystem elements, such as green areas and rivers (Tarr, 2002); and (iii) the political ecology of distribution conflicts related both to access to resources such as clean air, and to exposure to pollution and toxic waste (Heynen, Kaika, \& Swyngedouw, 2005). Collectively, these approaches relate the consumption of different flows to the functioning and reproduction of the system, capturing the diversity of functions and the dynamics of urban systems in biophysical and political terms. We add the societal focus to urban metabolism analysis by centring our study on the human dimension of informal settlements through demographic and economic data.

In order to analyse metabolic patterns, we used the Multi-Scale Integrated Assessment of Societal and Ecosystem Metabolism (MuSIASEM) accounting method (Giampietro \& Mayumi, 2000a, 2000b), and collected data through household surveys in the three informal settlements. MuSIASEM is informed by complexity theory, and analyses the biophysical flows consumed and produced by a system at multiple scales of analysis, and relates flows to funds, the structural and functional elements that determine the metabolic patterns of a system. Examples of fund elements in an urban context are: human activity, which determines the demand for water, energy and food; housing, which determines the demand for infrastructure such as sewerage and water pipes, electric grid, roads; installed power capacity, which determines the demand for electricity. MuSIASEM has been applied both at the country level (Giampietro, Aspinall, Ramos-Martin, \& Bukkens, 2014; Giampietro et al., 2012, 2013) and to urban metabolism studies (D’Alisa, Di Nola, \& Giampietro, 2012; Han et al., 2018; Lu et al., 2016). Its application in informal settlements is still limited to few studies (Kovacic \& Giampietro, 2017; Kovacic et al., 2016; Makinde, 2018; Smit et al., 2018).

Following the multi-scale approach of MuSIASEM, this paper focuses on human activity and installed power capacity (measured through home appliances) as funds, and on energy as flow. 


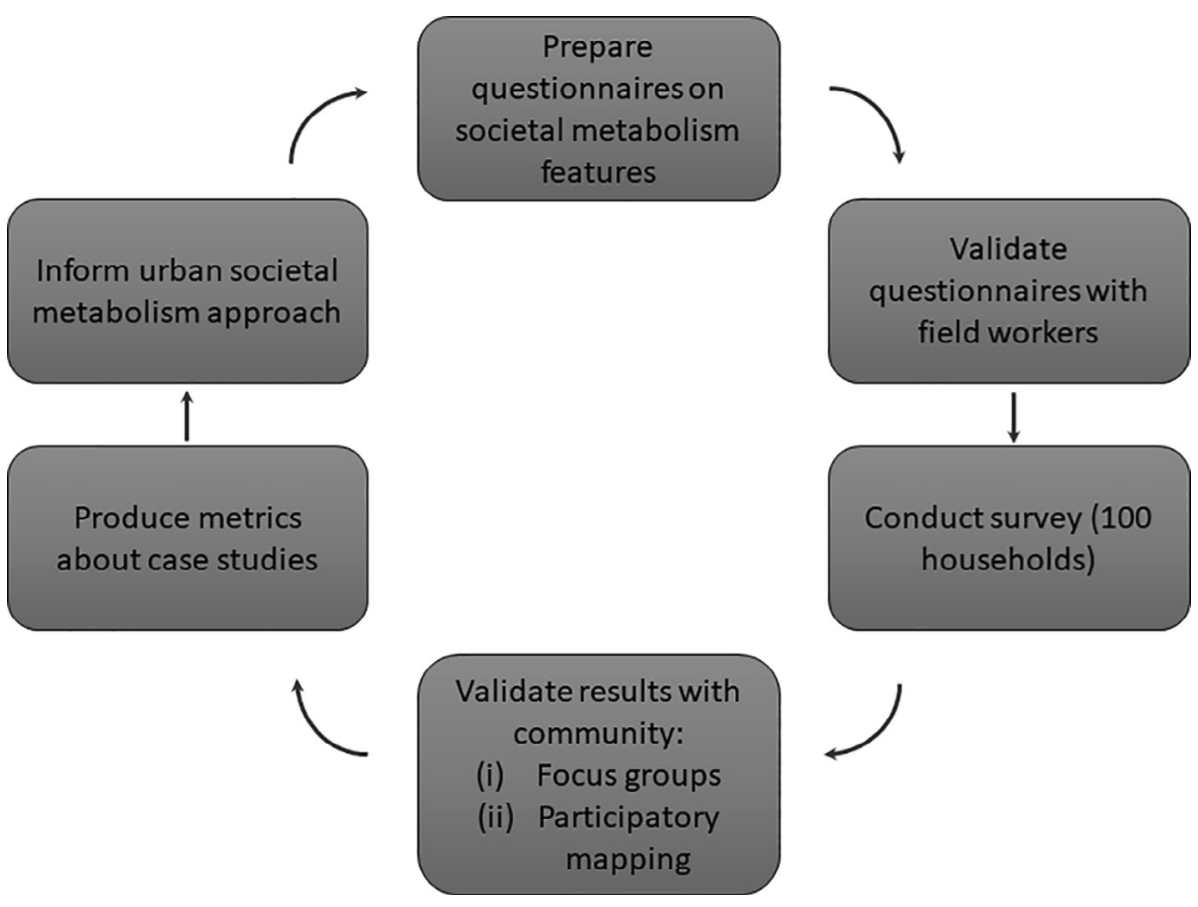

Fig. 1. Co-design research cycle.

Fund and flow elements are defined in this paper at different scales of analysis. With regard to human activity, we use three levels of analysis: (i) total population and population pyramid, at the settlement level; (ii) household composition, at the household level; (iii) time use, at the individual level. In all three levels, we analyse the gender balance and the differences in time use between genders at the individual level. The fund element installed power capacity was only analysed at the household level as home appliances. With regard to the energy flow, we refer to the household level and we distinguish between different end uses (cooking, lighting, heating and water boiling). Health and economic activity were included to link the study to human development indicators and initiate an interdisciplinary approach that combines urban metabolism to political ecology and political industrial ecology. Health is measured at the individual level (incidence of illnesses) and economic activities are reported at the settlement level (percentage of economic activities carried out within and outside the settlement) and at the individual level (occupation).

This method was combined with focus groups, in order to discuss the relevance of the quantitative findings, inconsistencies and gaps in the data, and the differences and nuances of each case study. The local communities took part, not only in the creation of knowledge, but also in the definition of the questions for the questionnaire, contributing to a co-design of the research (Ambole, Swilling, \& M'Rithaa, 2016). The research approach was based on iterative engagements as illustrated in Fig. 1. A first pilot survey was done in Enkanini in 2015 with 100 households (corresponding to 276 people). As results indicated that fuel choice was linked to health problems and safety hazards, health data were added through focus groups. The study was then replicated in 2017 with an expanded questionnaire that included questions about health, in Mathare and based on a sample of 100 households (corresponding to 362 people), and in Kasubi-Kawaala, based on a sample of 100 households (corresponding to 406 people). The sample size was set to 100 households for all case studies to have comparable samples. We limited the number of surveys because the aim of the study was to identify patterns or trends in societal metabolism, rather than to provide a quantitative description of the whole settlement. The sample size chosen is consistent with other studies in the literature (Parikh, Fu, Parikh, McRobie, \& George, 2015; Shrestha, Kumar, Martin, \& Dhakal, 2008). The update of the survey for use in Mathare and Kasubi-Kawaala, represented a full-cycle in the co-design process.

In Enkanini and Mathare, the questionnaires were administered by field workers hailing from the community and experienced in data collection. In Enkanini, the field workers were associated to the Enkanini Research Centre Association (ERCA). In Mathare, the field workers were associated with Slum Dwellers International ${ }^{1}$. In both study sites, the field workers were trained, had experience collaborating with research projects, and leveraged on their relationships with the community, which facilitated the completion of the questionnaires. In Mathare, some questionnaires were coconducted by university researchers.

Administration of the surveys were followed up by focus group discussions with field workers and community members who participated in the survey, to address unexpected results, data gaps and uncertainties, and to give space for the reflection and feedback from the community members and field workers. In Mathare, one focus group was organized in April 2018 with 12 participants, including the field workers and community members who had participated in the survey. Mathare field workers reported that as the questionnaire asked about both fuel choice and health issues, it helped raise awareness about respiratory diseases caused by indoor burning of charcoal and paraffin. In Enkanini, three focus groups were organized in June 2016. The three focus groups consisted of 10 participants each, which had been part of the survey, divided by their energy use profile (solar panel users, indirect electricity users, and others) (Smit, Musango, \& Brent, 2019). Residents expressed their concern about the consequences of electricity provision initiatives and the recognition of the settlement (see also Kovacic et al., 2016). The use of focus groups further reinforced co-design as a central component of the study.

In Kasubi-Kawaala, questionnaires were administered by researchers from the Urban Action Lab in Makarere University. 
Although the university has strong ties with the settlement, through research projects and collaborations, the questionnaire was not administered by community-based organisations and follow-up focus groups have not been organised yet. Some of the answers indicate that the interviewees might have felt defensive. For instance, respondents did not elaborate on their health conditions and repeatedly argue that health issues were not related to fuel choice. The difficulties encountered speak to the need to include the community in the research design, and not just as research informants.

The data collection process is vulnerable to data gaps when commitment to the research is not shared by the local community. Vague answers may be associated with a sense of shame, both with regard to poverty and to jobs, and to a lack of trust when it comes to informal, and sometimes illegal, activities. Household composition was not always easy to define, especially in cases in which a household member (generally the husband) works in rural areas and only occasionally visits the family, in cases of polygamous husbands, and in cases in which children are sent to boarding school.

The combination of data collection and participatory methods for the discussion and validation of data provided flexibility to the study, and made it possible to include new questions in the revised version of the questionnaire. As a result, the data collection process and the research design were adapted to each case study, and the quantitative analysis did not smooth out differences. The drawback of this approach is that there are differences in the data collected in the three case studies, namely: (i) questions about health and home appliances were added in the second cycle of surveys, and data for Enkanini were obtained only through focus groups, therefore Tables 3 and 4 in Section 4 only include data for Mathare and Kasubi-Kawaala. (ii) The difficulties in engaging with the community in Kasubi-Kawaala resulted in incomplete questionnaires with regard to time use data, therefore we were not able to analyse individual time use for Kasubi-Kawaala. (iii) As not all questionnaires were fully completed in Kasubi-Kawaala, we restricted our analysis of individual level data (economic activity and health) to 72 questionnaires, to ensure consistency of data for comparison purposes.

\section{Results}

This section reports the results of the societal metabolism analysis of informal settlements. The section is divided in four parts: (i) human activity, which is analysed at the level of the settlement, of households and of individuals; (ii) energy consumption and installed power capacity at the level of households; (iii) health at the level of individuals; and (iv) economic activity, at the level of the settlement and of individuals. The results of the societal metabolism analysis are compared to the standard indicators used by the UN, to highlight the insights gained from the multi-scale and metabolic approach towards a nuanced use of quantitative information.

\subsection{Human activity}

At the level of the settlement, we analysed the demographic structure of the population. All three settlements are characterised

\footnotetext{
2 In Enkanini, about 30\% of the population is aged younger than 15 years old, and less than $1 \%$ is aged 60 or more. The national average for South Africa is about $30 \%$ aged younger than 15 years old and $8 \%$ aged 60 or more (STATS SA, 2012). In Mathare, about $37 \%$ of the population is aged younger than 15 years old, and about $4 \%$ are aged 60 or more. The national average for Kenya is about $40 \%$ aged younger than 15 years old and about 3\% aged 60 or more (Kenya National Bureau of Statistics. (2009), 2009). In Kasubi-Kawaala, about $43 \%$ of the population is aged younger than 15 years old, and $2 \%$ is aged 60 or more. The national average for Uganda is about $48 \%$ aged younger than 15 years old and $2 \%$ aged 60 or more (Uganda Bureau of Statistics, 2014).
}

by a young population, similar to the national average of each country. No distinctive differences were observed in age structure ${ }^{2}$. At this level of analysis, the gender distribution is fairly balanced, with a slight majority of women in all three settlements (between $52 \%$ and 54\%). Our results are similar to standard indicators on gender balance, which refer to the population of informal settlements as a whole (UN-HABITAT, 2003). However, the gender structure is unevenly distributed in different age groups. Gender distribution is balanced in children and teenagers (ages 0-19), but all three informal settlements are characterized by a strong gender asymmetry in working age adults, with between 60\% (Kasubi-Kawaala), 63\% (Enkanini) and 75\% (Mathare) more women than men in the age range $20-34^{3}$ (Fig. 2). The use of multiple levels of analysis reveals the gender asymmetry, which is not captured by standard indicators.

This gender distribution asymmetry suggests that men are more likely to leave informal settlements as they reach adulthood. Nelson (1978) observes that daughters tend to remain with their mothers while sons move away. From the focus groups, we learned that adult men may work outside of the settlement and provide for their families leaving the women behind with the children, and that women are more likely to find means of subsistence that can be exercised from their homes, such as washing clothes, cooking food for their neighbours, and prostitution (Nelson, 2013).

The gender asymmetry can also be observed at the household level. Single mother households represented between 20\% (Enkanini), 24\% (Kasubi-Kawaala) and 30\% (Mathare) of total households (Fig. 3). As has been widely documented in the literature (Agarwal, 1986; Moser, 1989; Nussbaum, 2001), social and economic risks are absorbed by women. Our results add to existing understanding with the finding that informal urban settlements across all case studies are inhabited predominantly by women. This trend can be seen as an "expected pattern" in metabolic terms. In the case of Kasubi-Kawaala, the high percentage of single mother households can be explained by socio-cultural factors, where, in the Muslim population, husbands may be polygamous and have multiple households. Further, the polygamous husbands are more likely to work in rural areas and only come home one day per week or less. In the case of Enkanini and Mathare, the prevalence of women cannot be explained only by looking at household composition, and necessitates a more fine-grained analysis of time use data as presented in Figs. 4 and 5 and Table 1 and 2.

At the individual level, we compared time use of men and women across age groups in Mathare and Enkanini ${ }^{4}$. In this case, gender asymmetries manifest in the differences in time use. In the case of Mathare (Fig. 4 and Table 1), the age group between 20 and 34 years showed that men spend, on average, 60\% more time than women in paid work. Paid work time includes commuting to and from work, which is considered as part of the time investment required by paid work activities. The higher standard deviation for women is due to the fact that unemployment is higher among women, causing greater variability in time use data. The difference was partially explained during the focus group by the fact that women tend to work closer to, or in, the settlement, and in some cases they report having less time to dedicate to paid work due to house chores and child care.

With regard to unpaid work, which includes caring for children and the elderly, cooking, housekeeping, collecting fuels and water, women in Mathare devote 6 times more time than men to unpaid work. It should be noted that unpaid work is underestimated for women because working from home often allows for multi-tasking. In cases of multi-tasking, we have attributed the

\footnotetext{
3 The age group between 20 and 34 was used because it provided the largest comparable dataset across the three case studies.

4 Due to the difficulties in data collection described in methods and data, time use data for Kasubi-Kawaala was not available.
} 
Enkanini

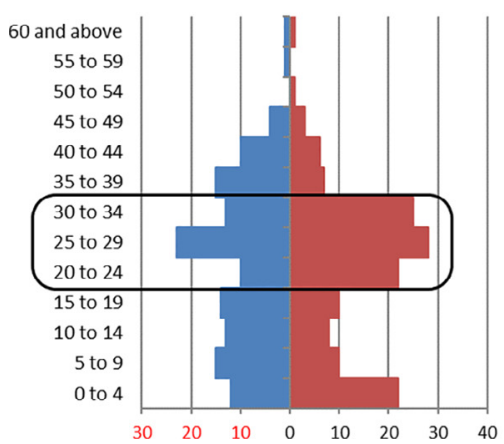

Mathare

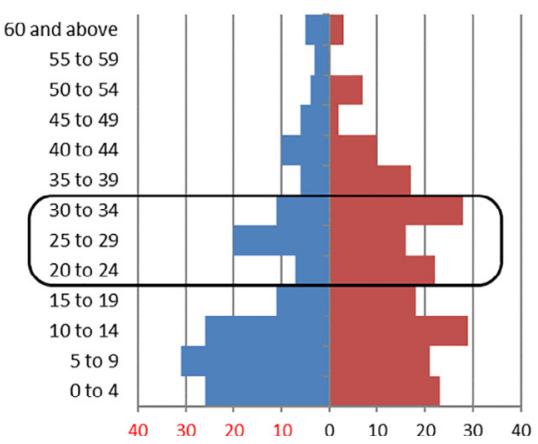

Kasubi-Kawaala

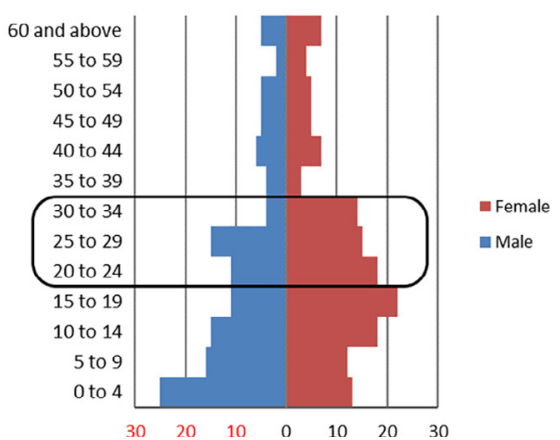

Fig. 2. Gender distribution by age groups.

Enkanini

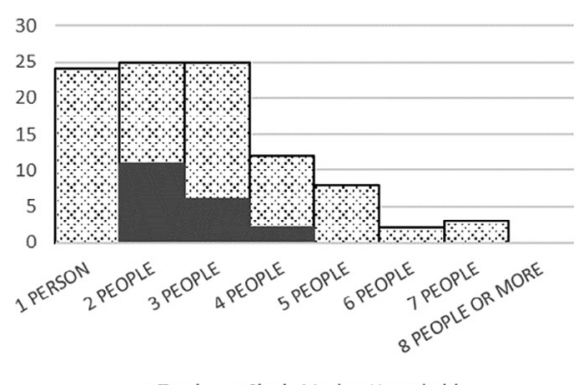

口Total $\square$ Single Mother Household
Mathare

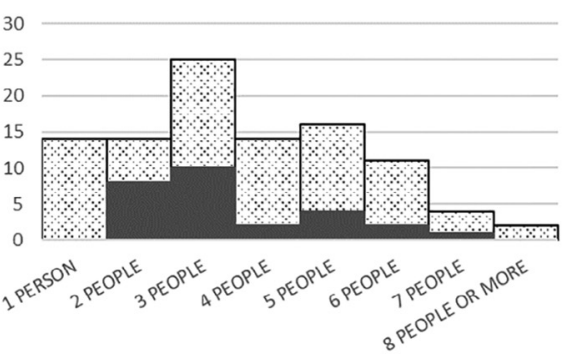

๑Total $\square$ Single Mother Households
Kasubi-Kawaala

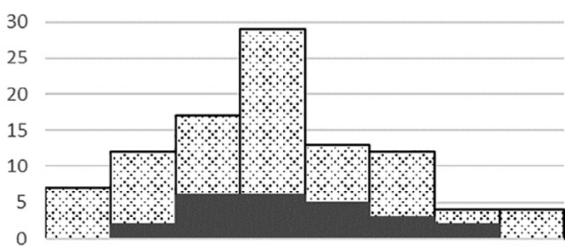

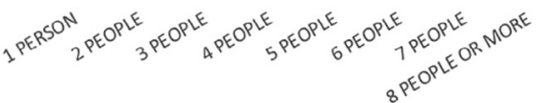

\Total $\square$ Single Mother Hoseholds

Fig. 3. Household composition and single-mother households.

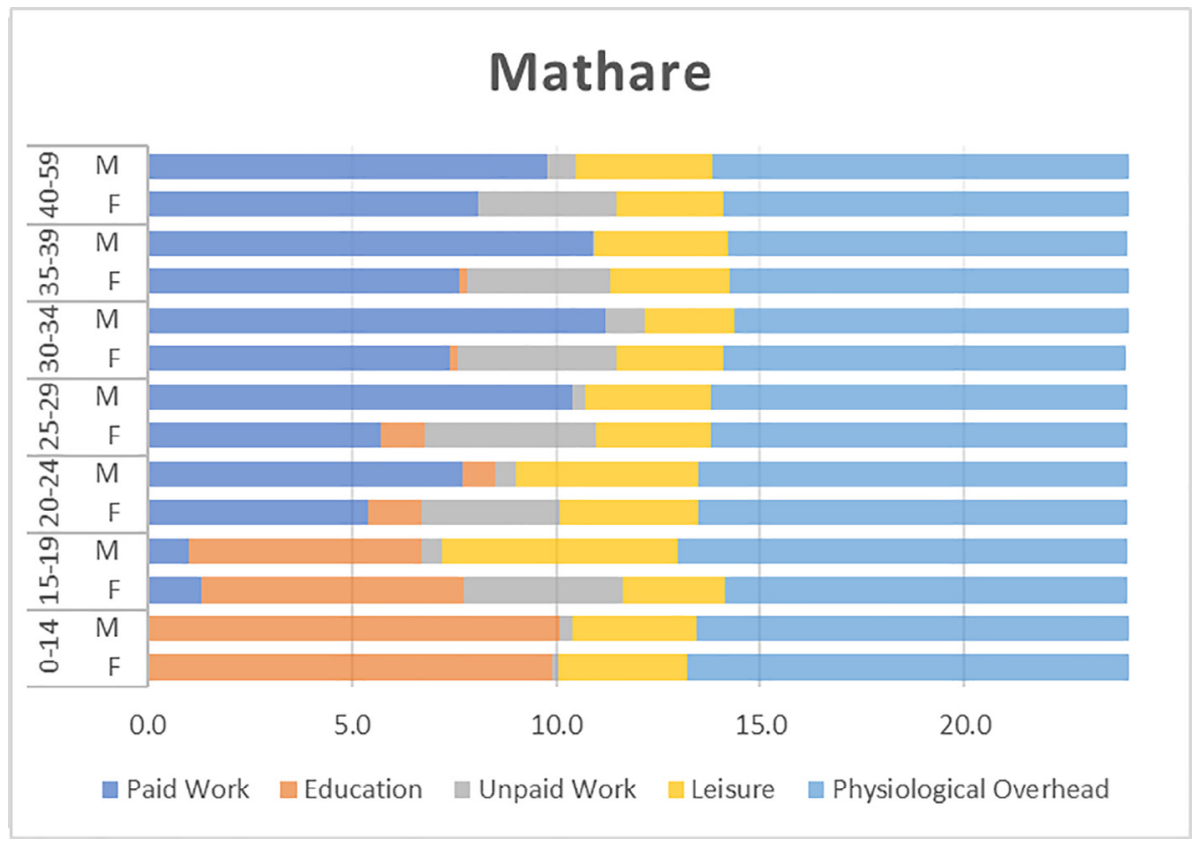

Fig. 4. Time use per gender and age group, Mathare.

hours to paid work in order to avoid double accounting and keep the total hours per day at 24. In the focus group, participants explained that women take care of children while attending to home-based businesses. The ability to carry out multiple tasks at once when working from home may explain why women tend to work more within the settlement than men, and why the settlement is inhabited by more women than men, among young working age adults.

It is noteworthy that $2 \%$ of the households in Mathare have house-help living with them. This does not indicate a wealthy 


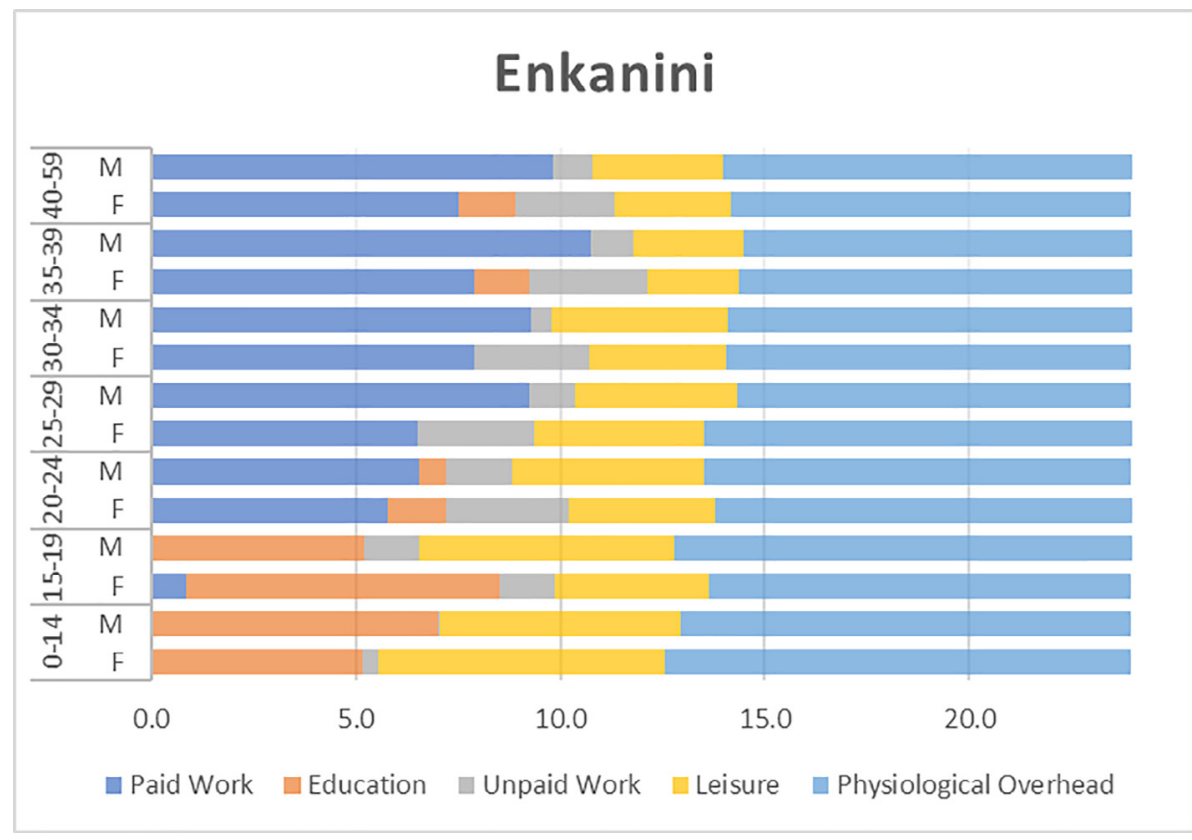

Fig. 5. Time use per gender and age group, Enkanini.

Table 1

Time use per gender and age group, Mathare.

\begin{tabular}{|c|c|c|c|c|c|c|}
\hline & & Paid Work & Education & Unpaid Work & Leisure & Physiological Overhead \\
\hline \multirow[t]{2}{*}{$0-14$} & $\mathrm{~F}$ & $0.0(0.0)$ & $10.2(2.4)$ & $0.1(0.2)$ & $3.1(1.5)$ & $10.6(1.3)$ \\
\hline & M & $0.0(0.0)$ & $10.3(1.7)$ & $0.3(0.9)$ & $3.0(1.2)$ & $10.4(0.9)$ \\
\hline \multirow[t]{2}{*}{$15-19$} & $\mathrm{~F}$ & $1.3(2.9)$ & $6.6(5.3)$ & $1.7(1.8)$ & $3.6(1.9)$ & $10.8(1.1)$ \\
\hline & M & $1.0(2.3)$ & $6.2(5.2)$ & $0.3(0.2)$ & $5.5(3.7)$ & $11.0(0.1)$ \\
\hline \multirow[t]{2}{*}{$20-24$} & $\mathrm{~F}$ & $5.5(5.3)^{\dagger}$ & $1.7(4.2)$ & $3.6(2.9)$ & $3.0(2.6)$ & $10.2(1.6)$ \\
\hline & M & $8.2(0.9)^{\dagger}$ & $0.7(1.5)$ & $0.5(1.0)$ & $4.3(1.0)$ & $10.3(0.5)$ \\
\hline \multirow[t]{2}{*}{$25-29$} & $\mathrm{~F}$ & $5.2(4.6)^{\dagger}$ & $1.0(4.3)$ & $5.6(4.7)$ & $2.7(1.8)$ & $9.5(1.5)$ \\
\hline & M & $10.4(2.3)^{\dagger}$ & $0.0(0.0)$ & $0.3(0.7)$ & $3.1(2.1)$ & $10.2(1.1)$ \\
\hline \multirow[t]{2}{*}{$30-34$} & $\mathrm{~F}$ & $7.4(3.1)^{\dagger}$ & $0.2(1.2)$ & $4.4(2.4)$ & $2.4(1.4)$ & $9.6(1.4)$ \\
\hline & M & $11.2(2.2)^{\dagger}$ & $0.0(0.0)$ & $1.0(1.5)$ & $2.2(1.1)$ & $9.7(1.4)$ \\
\hline \multirow[t]{2}{*}{$35-39$} & $\mathrm{~F}$ & $7.4(4.2)^{\dagger}$ & $0.2(0.7)$ & $4.3(3.3)$ & $2.6(1.8)$ & $9.5(1.4)$ \\
\hline & M & $11.0(2.5)^{\dagger}$ & $0.0(0.0)$ & $0.0(0.0)$ & $3.2(1.4)$ & $9.8(0.9)$ \\
\hline \multirow[t]{2}{*}{$40-59$} & $\mathrm{~F}$ & $8.2(3.2)^{\dagger}$ & $0.0(0.0)$ & $3.4(2.2)$ & $2.7(2.2)$ & $9.7(1.2)$ \\
\hline & M & $9.8(2.9)^{\dagger}$ & $0.0(0.0)$ & $0.8(1.3)$ & $3.3(2.3)$ & $10.1(1.3)$ \\
\hline
\end{tabular}

Standard deviation reported in parenthesis.

$\dagger$ The sets of data for men and women are significantly different from each other, with $\mathrm{p} \leq 0.01$.

Table 2

Time use per gender and age group, Enkanini.

\begin{tabular}{|c|c|c|c|c|c|c|}
\hline & & Paid Work & Education & Unpaid Work & Leisure & Physiological Overhead \\
\hline $0-14$ & $\begin{array}{l}\mathrm{F} \\
\mathrm{M}\end{array}$ & $\begin{array}{l}0.0(0.0) \\
0.0(0.0)\end{array}$ & $\begin{array}{l}5.2(4.5)^{\dagger} \\
6.8(3.6)^{\dagger}\end{array}$ & $\begin{array}{l}0.4(0.9) \\
0.1(0.1)\end{array}$ & $\begin{array}{l}7.2(4.4) \\
6.1(3.5)\end{array}$ & $\begin{array}{l}11.2(0.7) \\
11.0(0.8)\end{array}$ \\
\hline $15-19$ & $\begin{array}{l}\mathrm{F} \\
\mathrm{M}\end{array}$ & $\begin{array}{l}0.9(2.7) \\
0.0(0.0)\end{array}$ & $\begin{array}{l}7.7(4.4)^{\dagger} \\
5.2(4.7)^{\dagger}\end{array}$ & $\begin{array}{l}1.3(1.5) \\
1.3(1.3)\end{array}$ & $\begin{array}{l}3.8(2.5) \\
6.3(4.7)\end{array}$ & $\begin{array}{l}10.3(0.7) \\
11.2(0.9)\end{array}$ \\
\hline $20-24$ & $\begin{array}{l}\mathrm{F} \\
\mathrm{M}\end{array}$ & $\begin{array}{l}5.5(4.9)^{\dagger} \\
6.8(4.6)^{\dagger}\end{array}$ & $\begin{array}{l}1.3(3.4) \\
0.7(2.1)\end{array}$ & $\begin{array}{l}3.2(2.4)^{\dagger} \\
1.9(1.9)^{\dagger}\end{array}$ & $\begin{array}{l}3.4(3.5) \\
3.9(2.0)\end{array}$ & $\begin{array}{l}10.5(1.1) \\
10.7(0.9)\end{array}$ \\
\hline $25-29$ & $\begin{array}{l}\mathrm{F} \\
\mathrm{M}\end{array}$ & $\begin{array}{l}6.5(4.8)^{\dagger} \\
9.7(3.7)^{\dagger}\end{array}$ & $\begin{array}{l}0.0(0.0) \\
0.0(0.0)\end{array}$ & $\begin{array}{l}2.8(1.1)^{\dagger} \\
1.2(1.1)^{\dagger}\end{array}$ & $\begin{array}{l}4.1(3.7) \\
3.6(2.6)\end{array}$ & $\begin{array}{l}10.5(1.3) \\
9.5(1.3)\end{array}$ \\
\hline $30-34$ & $\begin{array}{l}\mathrm{F} \\
\mathrm{M}\end{array}$ & $\begin{array}{l}7.8(3.9)^{\dagger} \\
9.3(3.8)^{\dagger}\end{array}$ & $\begin{array}{l}0.0(0.0) \\
0.0(0.0)\end{array}$ & $\begin{array}{l}2.9(1.2)^{\dagger} \\
0.5(0.7)^{\dagger}\end{array}$ & $\begin{array}{l}3.3(2.5) \\
4.3(2.4)\end{array}$ & $\begin{array}{l}9.9(1.4) \\
9.9(1.7)\end{array}$ \\
\hline $35-39$ & $\begin{array}{l}\mathrm{F} \\
\mathrm{M}\end{array}$ & $\begin{array}{l}7.9(3.9)^{\dagger} \\
10.8(1.5)^{\dagger}\end{array}$ & $\begin{array}{l}1.4(3.6) \\
0.0(0.0)\end{array}$ & $\begin{array}{l}2.9(1.0)^{\dagger} \\
1.0(1.1)^{\dagger}\end{array}$ & $\begin{array}{l}2.2(1.2) \\
2.7(1.7)\end{array}$ & $\begin{array}{l}9.6(1.1) \\
9.5(0.8)\end{array}$ \\
\hline $40-59$ & $\begin{array}{l}\mathrm{F} \\
\mathrm{M}\end{array}$ & $\begin{array}{l}7.5(5.3)^{\dagger} \\
9.8(3.3)^{\dagger}\end{array}$ & $\begin{array}{l}1.4(2.9) \\
0.0(0.0)\end{array}$ & $\begin{array}{l}2.4(1.8)^{\dagger} \\
0.9(1.0)^{\dagger}\end{array}$ & $\begin{array}{l}2.8(2.9) \\
3.2(2.9)\end{array}$ & $\begin{array}{l}9.8(1.4) \\
10.0(0.8)\end{array}$ \\
\hline
\end{tabular}

Standard deviation reported in parenthesis.

${ }^{\dagger}$ Data for men and women are significantly different from each other, with $\mathrm{p} \leq 0.01$. 
household, but makes it possible for women in those households to invest their time in paid work. The vulnerability of women to poverty, especially in single mother households, is therefore also linked to the asymmetric distribution of responsibilities within the household.

When aggregating paid work and unpaid work, both men and women in Mathare spend about $10 \mathrm{~h}$ per day on these activities, revealing that there are not significant gender disparities in time use, but that men tend to be remunerated for their work while women do more unpaid work. In the focus group, men were described as the breadwinners of the household. Paid work time often involves small businesses, such as eateries, washing clothes, and hawking. In these cases, working time (and income) is subject to demand and may vary from day to day. About $17 \%$ of working age adults (18-64 years old) are unemployed. All households have at least one family member who is employed, which means that unemployed people (mostly youth) are supported by their family members. Single mother households often declared that they receive transfers from the children's father.

In the case of Enkanini (Fig. 5 and Table 2), the results indicate that men work on average $20 \%$ more than women, for the age group between 20 and 34 years old. In this case, the distinction between genders is less marked for a variety of reasons: Enkanini is a much more recent settlement and has not (yet) developed a big internal economy, dwellers work outside of the settlement and mostly in Stellenbosch central, which is $4 \mathrm{~km}$ away from the settlement. There is, however, a sharp gender bias in the type of jobs that Enkanini's dwellers do: men are mostly employed as security guards and women are mostly employed as cleaners and domestic workers. Men tend to work slightly more than women due to the nature of their job: security guards work very long shifts, up to $12 \mathrm{~h}$ per day. With regard to unpaid work, also in this case, women devote almost 3 times more time than men to unpaid work.

Because women work mostly outside of the settlement, paid work time cannot be reconciled with other tasks, such as looking after children. For this reason, focus group participants reported that Enkanini hosts 5 creches, dubbed by Enkanini's dwellers as "dumping creches", where children are left during the day. About $30 \%$ of the working age population (18-64 years old) is unemployed. Higher unemployment in Enkanini (31\%) compared to Mathare (17\%) can be partially explained by the fact that women do not manage to work outside of their homes while attending to children. If unable to pay for the creche, they face higher entry barriers to the job market. In the case of Enkanini, there are households in which no one is employed, and they correspond to single mother households. Unemployed single mother households subsist on grants for child support by the South African government. About
54\% of households in Enkanini receive government grants in support of their children, which corresponds to 330 Rand per month (approximately 25 US\$). The allowance makes it possible for these families to partially attend to their basic needs.

The quantification at multiple levels of analysis shows both trends and differences between the informal settlements. More women than man in working age live in all three case studies, but differences emerge in unemployment rates, depending on whether women are able to work from home and reconcile working time with child care or whether they have to chose between child care and work. The higher amount of home based businesses, in turn, creates a parallel informal economy, which in the case of Mathare has ties with illegality and stigmatisation of the settlement.

\subsection{Energy and installed power capacity}

Standard statistics for energy report the percentage of population that has access to electricity, the use of traditional fuels and only considers infrastructure for transport (UN-HABITAT, 2003). Overall, energy consumption is correlated to population, and does not provide information about differences between the settlements. We distinguish between different energy uses in order to identify the drivers of fuel choice. We consider four energy uses: heating, lighting, cooking and water heating. The focus on installed power capacity, extends the analysis of infrastructure to the household level. Our results show that the three settlements have quite different energy mixes (see Fig. 6).

In Enkanini, paraffin is the predominant fuel, followed by gas, used for cooking and water heating, and solar energy, used mainly for lighting. In Mathare, paraffin is similarly the predominant choice for cooking and water heating, followed by electricity for lighting and water heating, and charcoal for heating and cooking. In Kasubi-Kawaala, charcoal is the dominant choice of fuel for cooking and water heating, followed by electricity for lighting. Heating is far less used in Mathare and Kasubi-Kawaala because of the milder weather conditions.

The focus groups revealed that the use of paraffin is very widespread in Enkanini and Mathare because the fuel can be used for multiple purposes, helping to limit household expenditure on energy. The fuel mixes also reflect the intervention of different projects in the settlements, which aimed at reducing energy poverty: the introduction of solar panels can be observed in Enkanini, and the use of briquettes, bio-char produced from organic waste, in Kasubi-Kawaala.

Electricity, conversely, is used predominantly for lighting in all three case studies, revealing a lower capacity to attend the energy

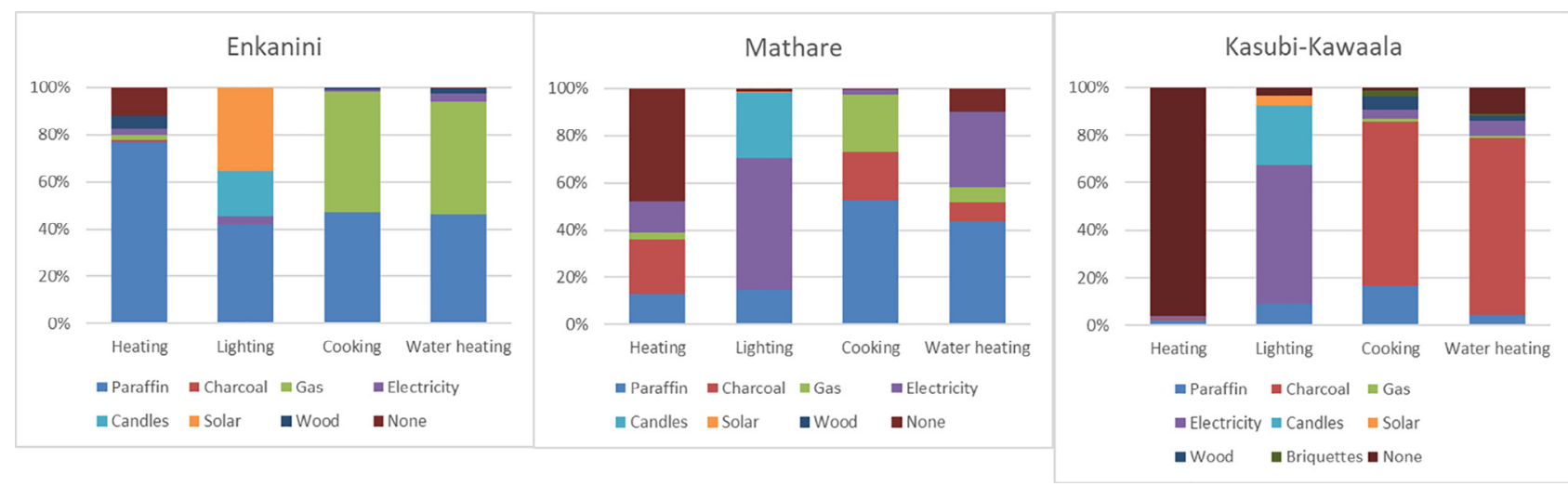

Fig. 6. Energy mix of Enkanini, Mathare and Kasubi-Kawaala, per end use, at the time of the surveys. 
needs of informal dwellers. Access to electricity is very different in the three case studies.

Enkanini did not have access to electricity at the time of the survey because the settlement is not formally recognized by the local municipality. However, the settlement is located close to Kayamandi, a formally recognized and planned township, on one side, and to an industrial area on the other side. Some residents of Enkanini were formerly backyard shack dwellers in Kayamandi and have access to indirect connections through tapped wires from their former landlords. As a consequence, all electricity connections in Enkanini are indirect. Only about $10 \%$ of residents have access to indirect electricity (Smit et al., 2018).

Enkanini is also serviced through the iShack project, which provides shacks with a small rooftop solar photovoltaic system at a monthly cost. The technology was provided free of charge, and residents were required to pay a monthly fee of 150 Rand (equivalent to about 11 US\$) for maintenance and repair services. The project received financial support from the Bill and Melinda Gates Foundation, the South African Green Fund, and policy support from the local municipality. From 2012 to 2015, about 24\% of Enkanini's households were equipped with a solar panel. Overall, access to electricity (solar and indirect) amount to $34 \%$, leaving about $66 \%$ of households unserviced (Smit et al., 2018).

As discussed in the focus groups, solar panels are not perceived by the dwellers as equivalent to grid electricity, because the electricity provided and the storage capacities are limited. Indirect connections to the grid are also unstable because of the poor quality of connections and which are prone to power cuts (Smit et al., 2019). In both cases, electricity supply allows only for lighting and the use of small electric appliances. As a consequence, the level of installed power capacity in Enkanini is also very low. There are only 5 fridges in the settlement as a whole, which are shared among neighbours, and only $20 \%$ of households own a television (Kovacic \& Giampietro, 2017).

The relationship between energy consumption and home appliances is explained by the MuSIASEM method as the relationship between funds and flows. The energy flow depends on the types and quantities of home appliances used. For instance, households that own a paraffin stove, will consume paraffin as their fuel. Causality runs also the other way: the availability of more fuel types makes it possible for households to own more than one type of stove, and makes them able to switch between one fuel and the other in response to price increases. Due to the relevance of installed power capacity to understand the energy consumption of households, the expanded questionnaire used for Mathare and Kasubi-Kawaala also asked about home appliances.

In Mathare, 93\% of sampled households have access to electricity. The settlement is connected to the electric grid, supplied by the national utility Kenya Power and Lighting Company (KPLC). However, a high proportion of households has indirect connections. In $50 \%$ of households, electricity supply is indirect and in another $10 \%$ connections are both direct and indirect. As revealed by the focus group discussion, this is due to the high presence of cartels, organized groups composed mostly of unemployed youth, who tap water pipes and electricity cables and act as intermediaries in the provision of these utilities as a means of income. Tapped electric connections are dangerous, and $15 \%$ of our sample reported problems of fire outbreaks from electric cables, damage to electric appliances owing to power surges, and electric shocks to household members. According to Ahmed et al. (2014), power cuts also affect street food vendors, adding to the precarity of their income.

The higher access to electricity of this settlement allows for a higher level of installed power capacity. Table 3 reports the percentage of households in our sample that owns each type of home appliance listed. The most used types of lightbulbs are energy saving lightbulbs (38\%) and incandescent lightbulbs (53\%), which are
Table 3

Home appliances owned by households in Mathare and Kasubi-Kawaala.

\begin{tabular}{|c|c|c|c|}
\hline Purpose & Type of home appliance & Mathare & $\begin{array}{l}\text { Kasubi- } \\
\text { Kawaala }\end{array}$ \\
\hline Lighting & $\begin{array}{l}\text { Incandescent lightbulbs } \\
\text { Energy saving lightbulbs } \\
\text { Paraffin lamp } \\
\text { Other (fluorescent lightbulbs, solar } \\
\text { lamps, electric lantern, torch) }\end{array}$ & $\begin{array}{l}53 \% \\
38 \% \\
23 \% \\
8 \%\end{array}$ & \begin{tabular}{l|l}
$4 \%$ \\
$81 \%$ \\
$9 \%$ \\
$16 \%$
\end{tabular} \\
\hline Cooking & $\begin{array}{l}\text { Gas cooker } \\
\text { Paraffin stove } \\
\text { Charcoal burning stove } \\
\text { Other (Wood burning stove, briquette } \\
\text { burning stove, electric cooker) } \\
\text { Microwave } \\
\text { Fridge }\end{array}$ & $\begin{array}{l}40 \% \\
89 \% \\
33 \% \\
5 \% \\
\\
5 \% \\
9 \%\end{array}$ & \begin{tabular}{l|l}
$2 \%$ \\
$14 \%$ \\
$78 \%$ \\
$12 \%$ \\
\end{tabular} \\
\hline Water boiling & $\begin{array}{l}\text { Gas cooker } \\
\text { Paraffin stove } \\
\text { Charcoal burning stove } \\
\text { Boiler or Electric immersion heater }\end{array}$ & $\begin{array}{l}4 \% \\
55 \% \\
15 \% \\
40 \%\end{array}$ & $\begin{array}{l}- \\
12 \% \\
40 \% \\
9 \%\end{array}$ \\
\hline Heating & $\begin{array}{l}\text { Paraffin stove } \\
\text { Charcoal burning stove } \\
\text { Electric heater } \\
\text { Incandescent lightbulbs }\end{array}$ & $\begin{array}{l}13 \% \\
23 \% \\
5 \% \\
8 \%\end{array}$ & $\begin{array}{l}2 \% \\
1 \% \\
1 \% \\
-\end{array}$ \\
\hline Entertainment & $\begin{array}{l}\text { Television } \\
\text { Home theatre } \\
\text { DVD } \\
\text { Radio } \\
\text { Computer }\end{array}$ & $\begin{array}{l}72 \% \\
10 \% \\
27 \% \\
51 \% \\
2 \%\end{array}$ & $\begin{array}{l}64 \% \\
11 \% \\
18 \% \\
34 \% \\
5 \%\end{array}$ \\
\hline Other & $\begin{array}{l}\text { Mobile phone } \\
\text { Iron }\end{array}$ & $\begin{array}{l}96 \% \\
24 \%\end{array}$ & $\begin{array}{l}78 \% \\
58 \%\end{array}$ \\
\hline
\end{tabular}

used also for heating. In the case of cooking devices, households often own more than one device, which gives them flexibility in the choice of cooking fuel. For water boiling, the most popular choices are electric devices (40\%) and paraffin stoves (55\%). Choice of fuel is influenced by cost ( $64 \%$ of respondents), ease of use ( $70 \%$ of respondents), and ease of access (54\% of respondents). Health outcomes are only considered by $7 \%$ or our respondents.

Almost all households (96\%) in the Mathare sample own at least one mobile phone, with an average of 1.5 cell phones per household. Cell phones are vastly used as means of banking and money transfer (mobile money), for betting (80\% of respondents), and for money lending services such as M-shwari and M-pesa (about 18\% of the sample). Televisions are the most widely owned entertainment home appliance (72\% of household in the sample). The high ownership rate of televisions is linked to the social status that TV ownership is associated with. Overall, the greater access to electricity in Mathare presents higher access to electric appliances than in Enkanini, but ownership and use is limited by the cost of bigger home appliances. This can be observed with reference to refrigerators, which are owned by only $9 \%$ of households. Most dwellers buy food on a daily basis according to daily income, thus rarely have excess food that needs refrigeration.

In Kasubi-Kawaala, 85\% of households have access to electricity. Only $10 \%$ of households declared that they have indirect connections. Field workers reported that the number of indirect connections may be underestimated in the questionnaires, as people are unwilling to disclose illegal electricity use. Nonetheless, the lower level of indirect connections with respect to Mathare, confirms the assessment that Kasubi-Kawaala shares access to similar living conditions as the rest of the city, and can rather be characterised as a poor neighbourhood. Poverty is reflected in the fact that about $15 \%$ of households do not have access to electricity, rather than in the preference for indirect connections.

The most popular type of lightbulbs used is the energy saving lightbulbs ( $81 \%$ of households), which indicates a lower level of 
multiple use of lighting appliances, compared to Mathare and Enkanini. Also in this case, households own multiple cooking devices, and are able to use more than one fuel type, although preference is given to charcoal (78\%). For water boiling, the most popular choices are charcoal (40\%) and paraffin stoves (12\%). Fuel choice in this case largely reflects cultural preference for charcoal, which is related to traditional cooking methods. Respondents repeatedly declared strong preference for charcoal also during the survey: "There's no better option than charcoal" (Additional comments section on questionnaire). Other factors reported are cost ( $45 \%$ of respondents), ease of use (39\% of respondents), and ease of access ( $28 \%$ of respondents). Health consequences were not highlighted by any respondents. Rather, the respondents pointed out that when used outdoors, charcoal does not cause any nuisance.

Mobile phone ownership in Kasubi-Kawaala is very high (78\% of households), with an average of 2 cell phones per household, generally corresponding to the number of adults. In this case, residents have access to bank services, and are less dependent on their cell phones for monetary transactions, compared to Mathare. Televisions are the most widely owned entertainment home appliance (64\% of household in the sample) as in the case of Mathare. There is great variability in the sample, due to the fact that KasubiKawaala is home both to poor households and wealthier households. Households in our sample thus vary from having no access to electricity, to one household who owns a television, home theatre, DVD, radio, microwave and a computer. Another indicator that differentiates Kasubi-Kawaala from the other two informal settlements is the ownership rate of refrigerators, at $20 \%$ of households. Refrigerators served as an indicator because they require 24 h supply of electricity, and thus a higher level of income. Once again, the refrigerator ownership rate indicates that KasubiKawaala is a poor neighbourhood, but it differentiates this settlement from Mathare and Enkanini.

The analysis of energy flows reveals that fuel choice is much more influenced by flexibility, both in the ability to use different fuels with the same appliance and in the possibility of using fuels and appliances to different purposes, than by distinctions between electricity and traditional fuels. We argue that the use of standard indicators, such as the percentage of the population that has access to electricity, may lead policies to focus on extending electricity access and disregard the specificities that lead to fuel choice in different localities. Differences between the three settlements are determined by cultural preferences, and differences in end uses (for example, not all settlements need heating).

\subsection{Health}

In the case of health, standard indicators report life expectancy, access to sanitation and waste collection services (UN-HABITAT, 2003, 2011). These indicators consider settlements as a whole. In our study, in addition to sanitation infrastructure for the settlements, we focus on the nexus between health and energy use, and provide a means of characterising health at the individual level.

The use of paraffin and charcoal produce smoke and are linked to health problems, especially when burnt indoors, including respiratory diseases (congested chest, shortness of breath, asthma, wheezing, pneumonia) and irritated eyes. Furthermore, the use of highly flammable fuels such as paraffin poses a high danger of fire. In the case of Enkanini, fuels are often burned indoors to provide heating during the winter months. Residents reported that it is not unusual for shacks to catch fire. The participants of the focus group also complain that paraffin affects the taste of food when used for cooking, but report having no other affordable choices.
Table 4

Health problems related to energy use, comparison of Mathare and Enkanini.

\begin{tabular}{lll}
\hline Health problem & Mathare & $\begin{array}{l}\text { Kasubi- } \\
\text { Kawaala }\end{array}$ \\
\hline Running nose & $42 \%$ & $26 \%$ \\
Congested chest \& Deep cough & $34 \%$ & $33 \%$ \\
Shortness of breath & $20 \%$ & $8 \%$ \\
Itchy/red eyes & $65 \%$ & $11 \%$ \\
Burns & $15 \%$ & $23 \%$ \\
Other respiratory diseases (Asthma, Wheezing, & $12 \%$ & $8 \%$ \\
$\quad$ Pneumonia, Respiratory tract infection) & & \\
Dizziness & $4 \%$ & $8 \%$ \\
Allergic reactions & - & $8 \%$
\end{tabular}

There are no health clinics in the informal settlement, and residents have to attend either the health clinic of neighbouring Kayamandi settlement or go to public hospitals, which are reported by the residents to be far away. For these reasons, residents report that they avoid seeking healthcare unless strictly necessary.

Because of the relevance of health problems related to energy use in Enkanini, the questionnaire was expanded for its use in Mathare and Kasubi-Kawaala, to capture also health issues. At the level of the whole settlement, there are significant differences between Mathare and Kasubi-Kawaala. Mathare has an important shortage of sanitation infrastructure. Most houses do not have a toilet and there are only 3 toilet blocks in the settlement, one of which is run as a business. Women prefer not to use public toilets at night for safety reasons. As a result of the dire sanitary conditions, cholera outbreaks are common (Nyamogoba et al., 2002). On the other hand, Kasubi-Kawaala has an open-air sewerage canal system, which reflects the low economic status of the settlement, but does not present major public health threats. A comparative analysis of health problems experienced at the individual level by household members is reported in Table 4. Respiratory diseases can also be linked to the high density of buildings and crowding, lack of ventilation in houses and shacks and, more generally, lack of spatial planning.

The analysis of health data indicates that a more detailed characterisation of health trends can be produced for individuals, that complements standard statistics on sanitation infrastructure. The analysis of this study, however, is very simple and does not suffice for a discussion of trends and differences between the three settlements. More research is needed to fill this gap.

\subsection{Economic activity}

With regard to economic indicators, standard measures refer to income per capita in terms of national averages, to inequality and to the percentage of the population below the poverty line (UNHABITAT, 2003, 2011). A major challenge in informal settlements is that income data is not available, as respondents with casual jobs and home-based businesses have variable incomes. Hence, statistics rely on averages and inequality indicators, which do not differentiate informal settlements from rural areas. In our study, we circumvent this data gap by analysing the informal economy at the settlement level and types of jobs for individuals.

At the level of the settlement, the three case studies differ vastly, in that Enkanini's economic activity is almost entirely oriented outside of the settlement. For this reason, Enkanini is characterised as a labour provider to the Stellenbosch town (Kovacic et al., 2016). In Mathare, the internal economy constitutes about $56 \%$ of overall economic activity, and consists entirely of informal economic activities. In Kasubi-Kawaala, the internal economy is also an important source of economic activity, not only for the settlement, but also for the city of Kampala. The economy of Kasubi-Kawaala is partially a formal economy, suggesting also in this respect that the settlement does not present the characteristics of a slum. 
The internal economy of Enkanini (in 2015) consisted of: 1 motor vehicle repairs, 1 rental agent, 1 gym, 1 beauty salon, 13 Spaza shops, 19 food services (tavern, hawkers, fast food services), 5 shebeens (business that serves drinks only), 69 subsistence crop farming sites, 2 animal farming sites ( 1 subsistence and 1 commercial), 1 commercial forestry farming, and 5 day care services (creches). In a population of about 8000 people, these businesses employ only 3\% of Enkanini's dwellers.

In Mathare, there is a burgeoning internal economy. The settlement is geographically organized around "main streets" with ample service offerings, ranging from eateries, butcheries, barber shops and beauty salons, as well as many home-based services such as washing clothes. About 56\% of respondents work within the settlement. It should be noted that the informal economy has close connections with the formal economy. For example, the numerous kiosks in Mathare sell items distributed by formal distributors or formal manufacturers, thus contributing to demand in the formal economy. Several of the casual labourers from Mathare work informally for formal businesses, e.g. registered construction companies.

Kasubi-Kawaala is home to the Kasubi market, one of Kampala's largest markets, which services residents of the whole city. The settlement is also located close to Makerere University, and offers accommodation to university students and staff, as well as fast food services for students. Kasubi-Kawaala is thus deeply integrated in the formal economy of Kampala. In addition, there are many informal businesses such as food vendors, washing clothes and other manual works. About $35 \%$ of respondents work within the settlement.

At the individual level, we analysed the types of job. Table 5 reports the 20 most recurrent occupations in the three settlements. From the data we also observed that Enkanini respondents work mostly outside of the settlement, in low paid positions, such as domestic and security workers. In Mathare, we observed the strong presence of the internal informal economy, with most respondents owning a small business, selling food and providing beauty salon and barber shop services. Construction is also a recurrent job in Mathare, which indicates that although the settlement has a large internal economy, it also acts as a labour provider.

In both Enkanini and in Mathare, a high percentage of respondents preferred not to specify their occupation, reported as "general worker" and "casual jobs" respectively. This is due to a variety of reasons, including: the volatile nature of many jobs, on which dwellers are contracted informally; the high recurrence of temporary jobs; a sense of shame with regard to certain occupations, such as washing clothes; and illegal occupations, which respondents prefer not to disclose. In the case of Mathare, the support received from within the community in administering the questionnaires enabled some respondents to indicate illegal occupations such as selling drugs, participation in cartels (selling water), and informal jobs (Jua kali). The high ratio of female respondents who preferred not to specify their occupation both in Enkanini and in Mathare could be partly linked to prostitution, especially if income gaps emerge associated with volatile occupations.

In the case of Kasubi-Kawaala, we observed that the most recurrent occupations were closely linked to the Kasubi market. The settlement also has a high number of small informal businesses, as well as many white-collar jobs, which include textile company supervisor, parking space manager, lawyer, bank manager, tobacco company manager, journalist. The settlement therefore presents characteristics both of informal settlements and of formal neighbourhoods. Moreover, there were no undeclared or vaguely specified jobs in the case of Kasubi-Kawaala, which may by partially due to the difficulties in data collection and may partially indicate that the level of informal and illegal activities is very low.

The analysis of the informal economy and of the types of jobs show a common trend of emergence of local and home-based businesses in informal settlements, but also reveal important differences between the three case studies. Enkanini's economy is externally oriented, Mathare's economy is inward looking, and Kasubi-Kawaala's economy is highly integrated in the city of Kampala. This diversity warns against the use of national averages that obscure differences and variability.

\section{Discussion}

The empirical analysis shows the different insights that are gained at different levels of analysis and, crucially, that some results are overlooked when using only one analytical level. Both gender asymmetries and energy consumption patterns cannot be differentiated by analysing the informal settlements in terms of total population and total energy consumption. We therefore argue that quantifying differences between informal settlements reveals windows for site-specific policy intervention. Based on these findings, we theorise that there is a role for non-standard quantification in informing policy, which leads the governance of urban

Table 5

20 most recurrent occupations in the three settlements.

\begin{tabular}{|c|c|c|c|c|c|c|c|c|c|c|c|}
\hline Enkanini & Total & $\mathrm{F}$ & M & Mathare & Total & $\mathrm{F}$ & M & Kasubi-Kawaala & Total & $\mathrm{F}$ & M \\
\hline Cleaner/Domestic worker & 26 & $92 \%$ & $8 \%$ & Small business & 35 & $69 \%$ & $31 \%$ & Market Vendor & 43 & $70 \%$ & $30 \%$ \\
\hline Security & 27 & $15 \%$ & $85 \%$ & Selling food & 31 & $84 \%$ & $16 \%$ & Small business & 18 & $22 \%$ & $78 \%$ \\
\hline Cashier & 13 & $77 \%$ & $23 \%$ & Salon/Barber Shop & 14 & $79 \%$ & $21 \%$ & Farmer & 12 & $67 \%$ & $33 \%$ \\
\hline General worker & 12 & $67 \%$ & $33 \%$ & Construction & 14 & $14 \%$ & $86 \%$ & White collar* & 9 & $33 \%$ & $67 \%$ \\
\hline Construction & 7 & $0 \%$ & $100 \%$ & Casual jobs & 9 & $44 \%$ & $56 \%$ & Mechanic & 5 & $0 \%$ & $100 \%$ \\
\hline Kitchen worker & 6 & $50 \%$ & $50 \%$ & Washing clothes & 8 & $100 \%$ & $0 \%$ & Teacher & 6 & $33 \%$ & $67 \%$ \\
\hline Farmworker & 6 & $50 \%$ & $50 \%$ & Boda boda & 4 & $0 \%$ & $100 \%$ & Boda boda & 6 & $17 \%$ & $83 \%$ \\
\hline Waiter & 5 & $100 \%$ & $0 \%$ & Home rental & 3 & $33 \%$ & $67 \%$ & Restaurant & 4 & $50 \%$ & $50 \%$ \\
\hline Packer & 4 & $50 \%$ & $50 \%$ & Electrician & 2 & $0 \%$ & $100 \%$ & House help & 3 & $100 \%$ & $0 \%$ \\
\hline Gardener & 4 & $0 \%$ & $100 \%$ & Mechanic & 2 & $0 \%$ & $100 \%$ & Salon & 3 & $100 \%$ & $0 \%$ \\
\hline Nurse & 3 & $67 \%$ & $33 \%$ & Plumber & 2 & $0 \%$ & $100 \%$ & Waitress & 3 & $100 \%$ & $0 \%$ \\
\hline Bank teller & 2 & $50 \%$ & $50 \%$ & Welding & 2 & $0 \%$ & $100 \%$ & Construction & 3 & $0 \%$ & $100 \%$ \\
\hline Municipality & 2 & $0 \%$ & $100 \%$ & Carrying luggage & 2 & $50 \%$ & $50 \%$ & Taxi driver & 3 & $0 \%$ & $100 \%$ \\
\hline Child caretaker & 2 & $100 \%$ & $0 \%$ & House help & 2 & $100 \%$ & $0 \%$ & Home rental & 2 & $100 \%$ & $0 \%$ \\
\hline Handicraft & 2 & $100 \%$ & $0 \%$ & Security & 2 & $0 \%$ & $100 \%$ & Electrician & 2 & $0 \%$ & $100 \%$ \\
\hline Plumber & 2 & $0 \%$ & $100 \%$ & Tailor & 2 & $0 \%$ & $100 \%$ & Butcher & 2 & $0 \%$ & $100 \%$ \\
\hline Welding & 2 & $0 \%$ & $100 \%$ & Waitress & 2 & $100 \%$ & $0 \%$ & Washing clothes & 2 & $100 \%$ & $0 \%$ \\
\hline Electrician & 1 & $0 \%$ & $100 \%$ & Jua kali & 2 & $50 \%$ & $50 \%$ & Boutique & 2 & $100 \%$ & $0 \%$ \\
\hline Fishery & 1 & $100 \%$ & $0 \%$ & Selling water & 2 & $50 \%$ & $50 \%$ & Security & 1 & $0 \%$ & $100 \%$ \\
\hline Police officer & 1 & $0 \%$ & $100 \%$ & Selling drugs & 1 & $100 \%$ & $0 \%$ & Carpenter & 1 & $0 \%$ & $100 \%$ \\
\hline
\end{tabular}


informality away from one-size-fits-all solutions without falling into policy paralysis. Before we unpack the theoretical implications of our work, we discuss the relevance of our results for the quantification of differences.

With regard to gender, the use of multiple levels of analysis is necessary to identify gender asymmetries. At the level of the community, one can quantify how many people live in each informal settlement and how many men and women there are. Such high level data, however, does not reveal gender asymmetries in our case studies because of the high number of children, among which gender distribution is balanced. Averages of the population as a whole and standardised census data hide the differences between genders. In our analysis, we shed light on the differences by analysing gender balance between different age groups, and by using a lower analytical level to study household composition. The high proportion of single mother households (about one third of each sample) is indicative of the concentration of urban poverty on women. Although the three informal settlements analysed are very different, the gender asymmetry is recurrent. This means that gender is a fruitful criterion to understand urban poverty and informality. The recurrent gender asymmetry can be considered as an expected metabolic pattern of urban informality. Poverty is generally reported to be more acute in rural areas (Gibson, 2015; Macours \& Swinnen, 2008), and women are characterised as being more vulnerable to poverty (Agarwal, 1986; Moser, 1989; Nussbaum, 2001). Our study shows that more women than men live in informal urban settlements, and that urban poverty is characterised by gender asymmetry.

The greater incidence of poverty among women in urban areas opens new questions for research and policy. Quantification that is restricted to counting the number of poor in a region or in a city, leads to an understanding of poverty as sort of Poverty Olympics, in which what matters is the greatest number, and of development policies as aimed at reducing poverty numbers, while struggling to act on the causes of poverty. The analysis of household composition and individual time use used in this paper sheds light on the gendered nature of urban informality and on the causes that tie women to informal settlements. These causes identified in this paper include:

- Women are more vulnerable to poverty because they are more likely to be responsible for unpaid work activities, such as childcare and house chores, which leaves less time for paid work;

- Women often depend on their partners for income and unemployment is higher among women;

- Women are likely to take low paid jobs such as washing clothes, cleaning, house help, small street-side or home-based eateries, which reinforce poverty because of the low income and volatile and informal nature of these jobs;

- Women are more often responsible for childcare, which forces them into home-based jobs that can be reconciled with childcare or excludes them from the job market if other childcare options are not accessible;

- Polygamous practices may generate a higher incidence of female-headed households.

With regard to energy consumption, the multi-level approach makes it possible to understand what drives energy choices. At the level of the settlement, data on energy consumption correlate to the number of people living in each settlement. Therefore, standardised data fail to capture differences between settlements, other than size differences. We assess energy consumption at the household level by referring to home appliances, and by distinguishing between different end uses. This analysis moves beyond the measurement of how much energy is used, and sheds light on the drivers of energy consumption and choice of fuel.
The differentiation between end uses shows that different types of fuels are used for different purposes. Electricity is mainly used for lighting, whereas paraffin, charcoal and gas are used for heating, cooking and water heating. The analysis of "energy" as a generic concept does not capture differences in use. Therefore, policies aimed at shifting overall consumption away from traditional fuels, such as paraffin and charcoal, and towards electricity, fail to respond to the energy needs of the urban poor. Electrification does not necessarily lead to lower consumption of charcoal, as in the case of Kasubi-Kawaala. Using electricity for cooking would require different stoves, which in turn affects the economy of the household. Nonetheless, electrification improves the living standards of informal settlements, for example by providing street lighting and making it safer for women to leave their houses at night.

In some case, energy policies that ban the use of certain energy sources, such as the charcoal ban recently introduced by the Kenyan government (Njenga, 2018), and promote the introduction of solar panels in Enkanini, have led to conflicts with and within informal settlement communities (Kovacic et al., 2016; Zibagwe, 2016). We argue that understanding the differences in energy consumption patterns sets the basis for energy policies that respond to the needs of the urban poor, rather than to generic principles of sustainability that promote the use of clean and renewable energies as blanket strategies.

Our results suggest that:

- The reliance on multiple fuels makes households more resilient to fluctuations in prices of paraffin, gas and charcoal;

- There is a preference for home appliances that can be used for multiple purposes, such as stoves that can be used both for heating and cooking;

- The use of paraffin and charcoal for multiple purposes means that fuels are burnt indoors, with adverse health consequences;

- Electricity consumption requires ownership of electric appliances and higher expenditure, which are incompatible with low incomes and irregular, temporary, volatile, seasonal incomes;

- Social preferences for traditional fuels such as charcoal are influential.

\section{Conclusion}

In this paper, we argue that different informal settlements raise different challenges of understanding and governance. Enkanini, the most recent settlement in our study, raises questions about the importance of tackling inequality as a policy priority, by showing how inequality and social exclusion contribute to the emergence of urban informality. Mathare, which is characterised by a high level of criminality, public health threats and stigmatisation, raises questions about the long-term effects of the formation of poverty enclaves. The deeply rooted segregation contributes to governance failure, and progress in urban electrification, for instance, does not directly benefit the urban poor as electricity provision is largely mediated by informal service providers ("cartels"). Informal settlements as Mathare raise attention to the fact that urban policy must concern itself not only with finding solutions, but also with policy implementation. Kasubi-Kawaala presents a different scenario, in which the informal settlement is well integrated with the city and stigmatisation of the area and its dwellers is minimal, although the settlement is still characterised by a high incidence of poverty. This case study challenges the association of informality with poverty, and of informal settlements with governance failure.

Collectively, the case studies show that it is important to understand differences, and to use accounting methods that provide an interface between the quantification of informal settlements and 
social, political and governance considerations. The starting point of the paper was the discussion of how urban informality cannot be understood through standardised measurements, and therefore cannot be governed through standard, or blueprint, policy measures. An example of standardising policy is universal electrification. In the case of Enkanini, electrification through solar panels improved safety through street lighting, but did not substitute the use of multi-purpose fuels such as paraffin and charcoal, and therefore did not improve energy poverty and energy related health problems.

With regard to measurement, we show that different levels of analysis produce different understandings of urban informality. Standard indicators focus on the aggregate level, by accounting for informal settlement population size and growth. These measurements are useful to plan for sanitation infrastructure, but do not provide information for site specific interventions. The analysis of households reveals the higher presence of women and singlemother households in informal settlements, and the analysis of individual time use explains the practices that lead to the higher presence of women, such as working in home-based businesses, childcare, etc. These insights can help identify windows for policy intervention. For instance, results suggests that policies aimed at the provision of day care for children and health care facilities within the settlement may contribute to poverty reduction among women, by reducing the time requirement of non-paid activities in favour of paid work time.

We argue that using quantitative data to identify differences, rather than to produce highly aggregated statistical information, leads to a different relationship between quantification and governance. The results of this paper do not give general answers to the problem of urban informality, but identify context-specific challenges, such as the relationship between choice of fuel, cultural preferences and multiple fuel uses, and between time use, gender inequality and home-based jobs. The reliance on the quantification of differences, as opposed to governance by standardisation, leads to the definition of modest, site specific, goals. Modest and localised goals should not to be seen as a second-best solution to global development goals. Highlighting differences produces a better understanding of the complexity of urban informality, but may also lead to policy paralysis. We argue that modest goals are a means of acting in the context of complexity, avoiding a policy paralysis.

\section{Declaration of Competing Interest}

The authors have no competing interests to declare.

\section{Acknowledgments}

This work was supported by the project Co-Dec (Co-designing energy communities with energy poor women in urban areas: case studies in Kenya, Uganda and South Africa), funded by the LIRA2030 (Leading Integrated Research for Agenda 2030 In Africa) programme. The first author received funding from the Stellenbosch University Research Office. The Nairobi team acknowledges the support from the African Leadership Program (AfriCLP) funded by the International Department Research Centre (IDRC). The authors also acknowledge the constructive comments and suggestions from two anonymous reviewers.

\section{References}

Acloly, C. (2000). Can urban management deliver the sustainable city? Guided densification in Brazil versus informal compactness in Egypt. In M. Jenks \& R. Burgess (Eds.), Compact cities: Sustainable urban forms for developing countries (pp. 127-140). London and New York: Spon Press.
Agarwal, B. (1986). Women, poverty and agricultural growth in India. Journal of Peasant Studies, 13(4), 165-220.

Ahmed, S., Simiyu, E., Githiri, G., Acioly, A., Mbaka, S., Karanja, I., \& Kigen, L. (2014) Dining with less danger: Mapping food and environmental hazards in Mathare, Nairobi. London: Briefing IIED.

Alkire, S., \& Santos, M. E. (2014). Measuring acute poverty in the developing world: Robustness and scope of the multidimensional poverty index. World Development, 59, 251-274. https://doi.org/10.1016/j.worlddev.2014.01.026.

Ambole, L. A., Swilling, M., \& M'Rithaa, M. K. (2016). Designing for informal contexts: A case study of Enkanini sanitation intervention. International Journal of Design, 10(3), 75-84.

Andvig, J. C., \& Barasa, T. (2014). A Political Economy of Slum Spaces: Mathare Valley (NUPI Working Paper No. 838). Oslo.

Bromely, R. (2004). Power, property, and poverty: Why De Soto's “Mystery of Capital" cannot be solved. In A. Roy \& N. AlSayyad (Eds.), Urban informality: transnational perspectives from the Middle East, Latin America, and South Asia (pp. 271-288). Lanham: Lexington Books.

D’Alisa, G., Di Nola, M. F., \& Giampietro, M. (2012). A multi-scale analysis of urban waste metabolism: Density of waste disposed in Campania. Journal of Cleaner Production, 35(November), 59-70.

Eckstein, S. (1990). Urbanization revisited: Inner-city slum of hope and squatter settlement of despair. World Development, 18(2), 165-181. https://doi.org/ 10.1016/0305-750X(90)90046-Z.

Giampietro, M., Aspinall, R. J., Ramos-Martin, J., \& Bukkens, S. G. F. (2014). Resource accounting for sustainability assessment: The nexus between energy, food, water and land use. In M. Giampietro, R. J. Aspinall, J. Ramos-Martin, \& S. G. F. Bukkens (Eds.), Oxon and New York: Routledge.

Giampietro, M., \& Mayumi, K. (2000a). Multiple-scale integrated assessment of societal metabolism: Integrating biophysical and economic representations across scales. Population and Environment, 22(2), 155-210.

Giampietro, M., \& Mayumi, K. (2000b). Multiple-scale integrated assessment of societal metabolism: Introducing the approach. Population and Environment, 22 (2), 109-153.

Giampietro, M., Mayumi, K., \& Sorman, A. H. (2012). The metabolic pattern of societies: Where economists fall short. London and New York: Routledge.

Giampietro, M., Mayumi, K., \& Sorman, A. H. (2013). Energy analysis for a sustainable future: Multi-scale integrated analysis of societal and ecosystem metabolism. London and New York: Routledge.

Gibson, J. (2015). Poverty measurement: We know less than policy makers realise (Working paper in economics No. 8/15). Hamilton.

Gilbert, A. (2007). The return of the slum: Does language matter? International Journal of Urban and Regional Research, 31(4), 697-713.

Gulyani, S., \& Talukdar, D. (2010). Inside informality: The links between poverty, microenterprises, and living conditions in Nairobi's slums. World Development, 38(12), 1710-1726. https://doi.org/10.1016/j.worlddev.2010.06.013.

Han, W., Geng, Y., Lu, Y., Wilson, J., Sun, L., Satoshi, O., ... Qian, Y. (2018). Urban metabolism of megacities: A comparative analysis of Shanghai, Tokyo, London and Paris to inform low carbon and sustainable development pathways. Energy, $155,887-898$.

Heynen, N., Kaika, M., \& Swyngedouw, E. (2005). In the nature of cities: Urban political ecology and the politics of Urban metabolism. London and New York: Routledge. https://doi.org/10.2747/0272-3638.28.2.206.

Huchzermeyer, M. (2006). The new instrument for upgrading informal settlements in South Africa: Contributions and constraints. In M. Huchzermeyer \& A. Karam (Eds.), Informal settlements: A perpetual challenge? (pp 41-61). Claremont: Juta and Company. https://doi.org/10.1016/S0197-3975(03)00058-4.

Kennedy, C., Pincetl, S., \& Bunje, P. (2011). The study of urban metabolism and its applications to urban planning and design. Environmental Pollution, 159(8-9) 1965-1973. https://doi.org/10.1016/j.envpol.2010.10.022.

Kenya National Bureau of Statistics. (2009). Population distribution by sex, number of households, area and density by county and district. Nairobi.

Kovacic, Z., \& Giampietro, M. (2017). Between theory and quantification: An integrated analysis of metabolic patterns of informal urban settlements. Energy Policy, 100(January), 377-386. https://doi.org/10.1016/j.enpol.2016. 06.047.

Kovacic, Z., Smit, S., Musango, J. K., Brent, A. C., \& Giampietro, M. (2016). Probing uncertainty levels of electrification in informal urban settlements: A case from South Africa. Habitat International, 56, 212-221. https://doi.org/10.1016/j. habitatint.2016.06.002.

Lu, Y., Geng, Y., Qian, Y., Han, W., McDowall, W., \& Bleischwitz, R. (2016). Changes of human time and land use pattern in one mega city's urban metabolism: A multi-scale integrated analysis of Shanghai. Journal of Cleaner Production, 133 (October), 391-401.

Lucci, P., Bhatkal, T., \& Khan, A. (2018). Are we underestimating urban poverty? World Development, 103, 297-310. https://doi.org/10.1016 j.worlddev.2017.10.022.

Macours, K., \& Swinnen, J. F. M. (2008). Rural-urban poverty differences in transition countries. World Development, 36(11), 2170-2187. https://doi.org/10.1016 j.worlddev.2007.11.003.

Makinde, O. A. (2018). Energy metabolism in a hybrid/multi-structured urban informal settlement. Stellenbosch University.

Ministry of Lands Housing and Urban Development. (2014). Slum settlements in Kampala. Kampala.

Moser, C. (1989). Gender planning in the Third World: Meeting practical and strategic gender needs. World Development, 17(11), 1799-1825. 
Nelson, N. (1978). Female-centered families: Changing patterns of marriage and family among Buzaa brewers of Mathare Valley. African Urban Studies, 3 (Winter), 85-103.

Nelson, N. (2013). "Selling her kiosk": Kikuyu notions of sexuality and sex for sale in Mathare Valley, Kenya. In P. Caplan (Ed.), The cultural construction of sexuality (pp. 229-251). Routledge.

Njenga, M. (2018, May). Banning charcoal isn't the way to go, Kenya should make it sustainable. The Conversation. Retrieved from https://theconversation.com/ banning-charcoal-isnt-the-way-to-go-kenya-should-make-it-sustainable95610.

Nuissl, H., \& Heinrichs, D. (2013). Slums: Perspectives on the definition, the appraisal and the management of an urban phenomenon. Journal of the Geographical Society of Berlin, 144(2), 105-116 https://doi.org/10.12854/erde144-8.

Nussbaum, M. C. (2001). Women and human development: The capabilities approach Cambridge, UK: Cambridge University Press.

Nyamogoba, H. D. N., Obala, A. A., \& Kakai, R. (2002). Combating cholera epidemics by targeting reservoirs of infections and transmission routes: A review. East African Medical Journal, 79(3), 150-155.

Parikh, P., Fu, K., Parikh, H., McRobie, A., \& George, G. (2015). Infrastructure provision, gender, and poverty in Indian slums. World Development, 66 468-486. https://doi.org/10.1016/j.worlddev.2014.09.014.

Pasha, A. (2017). Regional perspectives on the multidimensional poverty index. World Development, 94, 268-285. https://doi.org/10.1016/ j.worlddev.2017.01.013.

Pickvance, C. G. (2001). Four varieties of comparative analysis. Journal of Housing and the Built Environment, 16, 7.

Roy, A. (2005). Urban informality: Toward an epistemology of planning. Journal of the American Planning Association, 71(March), 147-158. https://doi.org/10.1080/ 01944360508976689.
Roy, A., \& AlSayyad, N. (2004). Urban informality: Transnational perspectives from the Middle East, Latin America, and South Asia. In Roy, A., \& AlSayyad, N., Eds. Lanham: Lexington Books.

Scott, J. (1998). Seeing like a state: How certain scheme to improve the human condition have failed. New Haven: Yale University Press.

Shrestha, R. M., Kumar, S., Martin, S., \& Dhakal, A. (2008). Modern energy use by the urban poor in Thailand: A study of slum households in two cities. Energy for Sustainable Development, 12(4), 5-13. https://doi.org/10.1016/S0973-0826(09) 60003-X.

Smit, S., Musango, J. K., \& Brent, A. C. (2019). Understanding electricity legitimacy dynamics in an urban informal settlement in South Africa: A community based system dynamics approach. Energy for Sustainable Development, 49, 39-52. https://doi.org/10.1016/j.esd.2019.01.004.

Smit, S., Musango, J. K., Kovacic, Z., \& Brent, A. C. (2018). Towards measuring the informal city. Journal of Industrial Ecology.

STATS SA. (2012). Census 2011. Pretoria.

Talukdar, D. (2018). Cost of being a slum dweller in Nairobi: Living under dismal conditions but still paying a housing rent premium. World Development, 109, 42-56. https://doi.org/10.1016/j.worlddev.2018.04.002.

Tarr, J. A. (2002). The metabolism of the industrial city: The Case of Pittsburgh. Journal of Urban History, 28(5), 511-545.

Uganda Bureau of Statistics. (2014). Population by parish. Kampala.

UN-HABITAT (2003). The challenge of slums - Global report on human settlements. London and Sterling: Earthscan Publications. https://doi.org/http://dx.doi.org/ 10.1108/meq.2004.15.3.337.3.

UN-HABITAT. (2011). Cities and climate change - Global report on human settlements 2011. London and Washington, DC.

Wolman, A. (1965). The metabolism of cities. Scientific American, 213(3), 179-190.

Zibagwe, S. (2016). Struggle for urban citizenship in South Africa: Agency and politics in the Enkanini upgrading project. Stellenbosch: Stellenbosch University. 